Jurnal PINUS: Jurnal Penelitian Inovasi Pembelajaran, 5 (2), 2020,1-10

Available online at: http://ojs.unpkediri.ac.id/index.

DOI: https://doi.org/10.29407/pn.v5i1.14230

\title{
PENGARUH PERMAINAN PUZZLE TERHADAP KEMAMPUAN PEMECAHAN MASALAH ANAK USIA 4-5 TAHUN
}

\author{
Rista Dwi Permata \\ rista.permata.rp@gmail.com \\ Pendidikan Guru Pendidikan Anak Usia Dini \\ Fakultas Keguruan dan Ilmu Pendidikan \\ Universitas Ronggolawe Tuban
}

\begin{abstract}
Abstrak
Pemecahan masalah merupakan salah satu aspek yang terdapat dalam ranah kognitif. Mengingat anak usia dini masih dalam tahap belajar mengenal kondisi lingkungan di sekitarnya, termasuk segala permasalahan yang ada, maka sangat dianjurkan kegiatan pembelajaran yang diberikan mengacu pada latihan pemecahan masalah. Anak belajar melalui bermain, dengan memanfaatkan media puzzle dapat melatih kemampuan berpikir anak dalam pemecahan masalah. Tujuan penelitian ini untuk mengetahui pengaruh penggunaan media permainan puzzle terhadap kemampuan pemecahan masalah anak. Rancangan pada penelitian ini menggunakan one group pretest-posttest design. Penentuan kelas eksperimen dilakukan secara acak. Penelitian ini diterapkan di TK PKK Harapan Rahayu Kecamatan Soko Kabupaten Tuban dengan sampel sebanyak 34 anak, kemudian dibagi menjadi 2 kelompok (eksperimen dan kontrol). Teknik pengumpulan data dalam riset ini memakai observasi dan dokumentasi. Riset ini memanfaatkan teknik analisis data yang bersifat deskriptif kuantitatif yang artinya mendeskripsikan data yang sudah terkumpul melalui kegiatan anak dan guru selama proses pembelajaran. Pelaksanaan analisis data dengan menggunakan uji Independent Samples Test yang menunjukkan hasil sig (2-tailed) sebesar $0,000<0,05$. Sehingga dapat disimpulkan bahwa media permainan puzzle berpengaruh dalam peningkatan kemampuan pemecahan masalah pada PAUD
\end{abstract}

Kata Kunci: puzzle, kemampuan pemecahan masalah, anak TK.

\begin{abstract}
Problem solving is one aspect contained in the cognitive. Considering that early childhood is still in the learning phase to be familiar with the conditions of the surrounding environment, including all existing problems, it is strongly recommended that the learning activities given refer to problem solving exercises. Children learn through play, by using puzzle media to practice their thinking skills in problem solving. The purpose of this study is to determine the effect of the use of puzzle game media on the ability to solve child problems. The design in this study uses one group pretest-posttest design. The class determination of the experiment was carried out randomly. This research was applied in PKK Harapan Rahayu Kindergarten, Soko District, Tuban Regency with a sample of 34 children, which were then divided into 2 groups (experimental and control). Data collection techniques in this research use observation and documentation. This research utilizes quantitative descriptive data analysis techniques, which means describing the data that has been collected through the activities of children and teachers during the learning process. The data analysis was carried out using the Independent Samples Test which showed a sig (2-tailed) result of $0,000<0.05$. So it can be concluded that the puzzle game media influence in improving problem solving abilities in early childhood.
\end{abstract}

Keywords: Puzzle, problem solving, childhood

Peer reviewed under responsibility of Universitas Nusantara PGRI Kediri.

(C) 2020 Universitas Nusantara PGRI Kediri, All right reserved, This is an open access article under the CC BY-SA license (https://creativecommons.org/licenses/by-sa/4.0/) 
Jurnal PINUS: Jurnal Penelitian Inovasi Pembelajaran, 5 (2), 2020, Rista Dwi Permata

\section{PENDAHULUAN}

Pendidikan dapat diartikan sebagai suatu usaha dalam meningkatkan kualitas seseorang, jenjang pendidikan yang dijadikan dasar penanaman segala ilmu pengetahuan terdapat pada jenjang usia dini.

Pendidikan akan terus berlangsung dari waktu anak itu lahir sampai usia enam tahun (lahir-6 tahun). Lembaga Pendidikan Anak Usia Dini disebut sebagai lembaga yang dibutuhkan dalam memaksimalkan segala kemampuan yang ada dalam diri anak, baik dalam hal intelektual, pembentukan karakter, sikap, dan wawasan dasar terhadap lingkungannya.

Masa yang tercepat dan tertepat dalam memberikan rangsangan atau stimulasi pada individu yaitu terdapat pada masa dini atau biasa disebut masa peka dengan segala potensi diri yang dimiliki masing-masing anak dapat dengan mudah dirangsang.

Periode emas ini hanya terjadi sekali sepanjang kehidupan manusia. Pernyataan tersebut sepaham dengan pendapat dari Maria (2008), menyatakan bahwa masa kehidupan yang terpenting bukanlah pada usia kuliah, melainkan pada masa pertumbuhan yang pertama, yaitu masa dari kelahiran hingga usia enam tahun.

Karena sangat pentingnya peran masa sensitif inilah diperlukan tindakan pengembangan yang menyeluruh serta melibatkan segala unsur mulai dari pengasuhan, kesehatan, pendidikan, dan perlindungan. Bermain menjadi salah satu cara yang akurat dalam usaha pengembangan yang menyeluruh. Hal ini dikarenakan masa dini merupakan masa bermain. Bermain selalu menjadi cara yang dapat membuat ketertarikan anak terhadap sesuatu.

Hal tersebut disebabkan karena anak mempunyai keistimewaan yang khas dan lain daripada orang dewasa, anak-anak cenderung energik, dinamis, antusias, dan mempunyai rasa keingintahuan yang tinggi terhadap apa yang dilihat, didengar, dan dirasakan.

Dengan demikian, karena anak berada pada periode emas dan keistimewaan yang dimiliki inilah diperlukan pendidikan bagi anak usia dini menggambarkan usaha sadar untuk mendidik dari orang dewasa, baik itu guru atau orang tua, yang mencakup segala tindakan dalam proses pengasuhan, perawatan, dan pendidikan terhadap anak sembari mengkondisikan situasi belajar yang nyaman dan kondusif bagi anak (menyenangkan) sehingga anak dapat belajar melalui pengalaman dan memberikan kesempatan bagi anak dalam mengetahui dan memahami lingkungan sekitar.

Tersedia banyak layanan pendidikan yang difokuskan untuk anak usia dini yang telah diatur oleh pemerintah, baik itu pendidikan formal, informal, atau nonformal. TK (Taman Kanak-Kanak) merupakan satuan pendidikan yang diutamakan untuk anak di usia dini dan termasuk dalam satuan pendidikan yang menangani anak usia dini dan termasuk dalam pendidikan bersifat formal, di dalam penyelenggaraannya difokuskan sebagai program pendidikan bagi seseorang dengan rentang usia empat tahun sampai 
Jurnal PINUS: Jurnal Penelitian Inovasi Pembelajaran, 5 (2), 2020, Rista Dwi Permata

dengan usia enam tahun (Sujiono, 2013).

Melalui lembaga pendidikan anak usia dini inilah anak-anak dididik dengan harapan agar segala potensi yang ditemukan dalam diri anak dapat berkembang dengan lebih baik tanpa adanya ketimpangan di salah satu aspek. Aspek perkembangan yang merupakan potensi dalam diri anak usia dini terdiri dari aspek nilai moral dan agama, bahasa, kognitif, sosial emosional, dan seni.

Menurut Permendikbud Nomor 137 Tahun 2014, salah satu aspek yang harus dikembangkan dalam diri anak yaitu, aspek perkembangan kognitif, khususnya keterampilan pemecahan masalah. Mengembangkan kemampuan kognitif anak sangatlah penting, dikarenakan aspek perkembangan kognitif merupakan pondasi bagi kemampuan anak untuk berpikir, berkreativitas, dan berkarya. Sedangkan menurut Dariyo (dalam Safitri, D., Syukri, M., 2014) mengutarakan bahwa aspek kognitif sebagai salah satu bidang pengembangan ketrampilan dasar dalam kurikulum TK memegang peranan yang vital dalam upaya mengembangkan ketrampilan berpikir anak supaya dapat mengelola perolehan belajarnya, dapat menjumpai bermacam-macam opsi penyelesaian permasalahan, mendukung anak untuk mengembangkan keterampilan logika matematikanya dan pemahaman akan ruang dan waktu serta ketrampilan untuk memilah-milah, mengklasifikasi serta merancang pengembangan keterampilan berpikir teliti.

Perkembangan kognitif memainkan peran esensial di sepanjang kehidupan individu, dengan keahlian awal dalam ranah kognitif berhubungan erat dengan banyaknya keuntungan dikemudian hari, seperti prestasi akademis yang membaik pada masa remaja, tingkat pendidikan yang lebih tinggi sepanjang hidup, kesehatan psikis yang lebih stabil, dan lebih sedikit waktu yang dihabiskan untuk menganggur (Kent, G., Pitsia, V., \& Colton, 2018)

Seberapa besar perkembangan kognitif anak bisa diamati saat anak mampu atau tidaknya anak dalam menyelesaikan masalah sederhana yang ditemui.

Kondisi yang ditemukan di lembaga TK PKK Harapan Rahayu Kecamatan Soko Kabupaten Tuban sebagian besar anak mengalami permasalahan dalam keterampilan pemecahan masalah. Hal tersebut diperlihatkan pada saat aktivitas pembelajaran yang peneliti amati, anak masih bingung dengan macam bentuk, belum dapat mencari penyelesaian suatu masalah yang sederhana seperti anak belum mengenal warna, dan masih terlihat sangat pasif.

$\begin{array}{ccr}\text { Selain } & \text { itu, } & \text { berdasarkan } \\ \text { pengamatan } & \text { peneliti, } & \text { aktivitas }\end{array}$ pembelajaran yang dilaksanakan di lembaga tersebut masih bersifat monoton. Pendidik masih sering menggunakan metode verbal dan minimnya penerapan media bermain yang dipakai dalam aktivitas pembelajaran sehingga membuat jalannya pembelajaran menjadi kurang diminati oleh peserta didik.

Pembelajaran untuk anak usia 
Jurnal PINUS: Jurnal Penelitian Inovasi Pembelajaran, 5 (2), 2020, Rista Dwi Permata

dini seharusnya lebih menekankan pada kegiatan bermain yang memang sesuai dengan dunia anak. Bermain merupakan kegiatan yang dilakukan untuk kesenangan yang ditimbulkannya tanpa mempertimbangkan hasil akhir (Hurlock dalam (Setyowati, 2018). Dengan kegiatan bermain dapat membantu anak dalam mengembangkan keterampilan pemecahan masalah dengan situasi yang menyenangkan, aktif, dan tanpa paksaan.

Aktivitas belajar yang lebih terpusat pada teacher center (berpusat pada guru) inilah yang mengakibatkan dimensi perkembangan kognitif anak menjadi kurang optimal. Bahkan tidak sedikit anak yang mengerjakan tugas hanya sekedarnya saja, ataupun anak menjadi mudah menyerah dan cenderung minta bantuan kepada gurunya untuk mengerjakan tugasnya.

Hal di atas terjadi disebabkan aktivitas pembelajaran kerap kali menggunakan buku majalah atau lembar kerja anak (LKA) yang mengakibatkan kelas menjadi kurang efektif dikarenakan anak merasa bosan dengan aktivitas pembelajaran sehingga anak lebih memilih kegiatan lain yang mereka senangi dan dianggap lebih menyenangkan (ramai sendiri).

Berdasarkan permasalahan tersebut, peneliti perlu melakukan upaya untuk meningkatkan kemampuan pemecahan masalah anak dengan memberikan kegiatan belajar melalui bermain meng-gunakan media permainan puzzle.

\section{KAJIAN PUSTAKA}

\section{Permainan Puzzle}

Menurut Moyles (dalam Safitri, D., Syukri, M., 2014) bermain merupakan satu proses yang diperlukan oleh anak-anak atau orang dewasa. Aktivitas belajar menggunakan media permainan puzzle ialah salah satu aktivitas yang dapat membuat anak tertarik untuk dapat lebih memperhatikan penjelasan pendidik dan juga dapat mempengaruhi kecerdasan kognitif anak usia dini. Media permainan puzzle merupakan media gambar yang masuk ke dalam jenis media visual karena bisa dicerna melalui indera penglihatan. Puzzle yakni permainan yang penggunaannya dengan menyusun kepingan-kepingan gambar menjadi satu bentuk yang utuh.

$$
\text { Menurut Martuti }
$$

kelebihan dari bermain puzzle bagi anakanak, salah satunya adalah meningkatkan keterampilan kognitif (cognitive skill) yang berhubungan dengan ketrampilan untuk belajar dan menyelesaikan masalah. Aktivitas bermain menggunakan media puzzle akan mengimplikasikan kerjasama antara tangan dengan mata sehingga anak memiliki keahlian dalam mendalami sesuatu hal menurut kemampuan dan minat anak.

Selain itu, dengan beraktivitas menggunakan puzzle dapat mengasah kemampuan otak anak dalam hal mengingat, mengenal bentuk, dan mengasah daya pikir. Media permainan Puzzle merupakan aktivitas membongkar dan menata kembali kepingan-kepingan 
Jurnal PINUS: Jurnal Penelitian Inovasi Pembelajaran, 5 (2), 2020, Rista Dwi Permata

gambar menjadi ke bentuk yang utuh (Depdiknas, 2006). Media permainan puzzle merupakan media permainan yang amat familier di kalangan pengajar atau di kalangan anak-anak, sehingga penggunaannya tidak membuat pemakai bingung dengan aturan mainnya.

Mutiah (2010) berpendapat, permainan ini tergolong jenis permainan pembangunan terstruktur yang dapat mengasah anak dalam hal berpikir dan memecahkan masalah. Sedangkan Malahayati (2009) mengatakan bahwa permainan puzzle mampu melatih ketajaman otak anak dalam menyusun atau merancang sesuatu dengan baik.

Berdasarkan hal di atas dapat diartikan bahwa media permainan puzzle merupakan media permainan yang bisa menunjang anak dalam meningkatkan aspek kognitif, yaitu kemampuan pemecahan masalah dalam diri anak dengan gaya yang menyenangkan bagi anak usia dini.

Terdapat beberapa manfaat dari bermain puzzle, hal ini sependapat dengan yang dipaparkan oleh Martuti (2008) yang menyatakan beberapa manfaatnya, yaitu:
a. Meningkatkan Keterampilan Kognitif;
b. Meningkatkan Keterampilan Motorik Halus;
c. Meningkatkan Keterampilan Sosial;
d. Melatih Koordinasi antara Mata dan Tangan;
e. Melatih Logika Melatih Kesabaran;
f. Memperluas Pengetahuan.

\begin{abstract}
Sedangkan Al-Azizy
(2010) menyebutkan manfaat dari bermain puzzle sebagai berikut:

a. Mengasah otak;

b. Melatih koordinasi antara mata dan tangan;

c. Melatih nalar;

d. Melatih kesabaran;

e. Menambah pengetahuan.

Dalam pernyataan tersebut, dapat diambil simpulan bahwa permainan puzzle memiliki manfaat dalam hal perkembangan kogntif anak. Dengan permainan tersebut dapat meningkatkan keterampilan kognitif, melatih logika, memperluas kesabaran, mengasah otak, melatih nalar, memecahkan masalah, dan sebagainya.
\end{abstract}

\section{Kemampuan Pemecahan Masalah}

Kemampuan pemecahan masalah merupakan salah satu kemampuan yang harus dikembangkan dalam diri anak usia dini, karena pemecahan masalah merupakan salah satu aspek yang terdapat dalam ranah perkembangan kognitif.

Santrock (2010) berpendapat bahwa proses kognitif merupakan perubahan dalam pemikiran, kecerdasan, dan kebahasaan anak. Proses berkembangnya kognitif memampukan anak untuk mengingat, membayangkan cara mempemecahan suatu persoalan, menyusun strategi, dan menghubungkan kalimat menjadi suatu pembicaraan.

Beaty \& Wortham (dalam
Syaodih, E., Setiasih, 2018)
mengemukakan bahwa kemampuan
pemecahan masalah pada anak usia dini 
Jurnal PINUS: Jurnal Penelitian Inovasi Pembelajaran, 5 (2), 2020, Rista Dwi Permata

adalah kemampuan anak untuk menggunakan pengalamannya dalam merumuskan hipotesis, mengumpulkan data, membuat keputusan tentang hipotesis, dan merumuskan kesimpulan tentang informasi yang mereka peroleh dalam proses ilmiah.

Sedangkan Solso (dalam Masyah, 2017) berpendapat bahwa, kemampuan pemecahan masalah adalah suatu pemikiran yang terarah secara langsung untuk menemkan suatu solusi atau jalan keluar untuk suatu masalah yang spesifik. Berdasarkan beberapa pendapat di atas, pemecahan masalah adalah kemampuan dalam menggunakan pengalamannya dalam menemukan solusi atas permasalahan yang dihadapi untuk menemukan jalan keluar.

Menurut Permendikbud 137 tahun 2014 tentang Standar Nasional Pendidikan Anak Usia Dini, tingkat pencapaian perkembangan anak (STPPA) pada usia 4-5 tahun untuk lingkup perkembangan belajar dan pemecahan masalah, yaitu:

1. Mengenal benda berdasarkan fungsi (pisau untuk memotong, pensil untuk menulis);

2. Menggunakan benda-benda sebagai permainan simbolik (kursi sebagai mobil);

3. Mengenal konsep sederhana dalam kehidupan sehari-hari (gerimis, hujan, gelap, terang, temaram, dsb);

4. Mengetahui konsep banyak dan sedikit;

5. Mengkreasikan sesuatu sesuai dengan idenya sendiri yang terkait

dengan berbagai pemecaham masalah;

6. Mengamati benda dan gejala dengan rasa ingin tahu;

7. Mengenal pola kegiatan dan menyadari pentingnya waktu;

8. Memahami posisi/kedudukan dalam keluarga, ruang, lingkungan sosial (misal: sebagai peserta didik/ anak/teman).

\section{METODE}

Penelitian ini merupakan jenis penelitian yang memanfaatkan pendekatan kuantitatif. Variabel terikat pada penelitian ini adalah kemampuan pemecahan masalah. Sedangkan variabel bebasnya adalah media permainan puzzle.

Penelitian ini dilaksanakan di TK PKK Harapan Rahayu Kecamatan Soko Kabupaten Tuban pada NovemberDesember 2019. Indikator yang digunakan dalam penelitian ini adalah (1) Memasangkan benda berdasarkan fungsinya, (2) Mengurutkan benda dari yang sedikit ke banyak, (3) Mengurutkan benda dari yang banyak ke sedikit, (4) Menyelesaikan waktu dengan batas waktu.

Pemberian nilai didasarkan pada pedoman penilaian dengan nilai-nilai yang memiliki rubrik penilaian, yaitu dengan menggunakan bintang 1 , bintang 2, bintang 3, dan bintang 4. Pengukuran kemampuan pemecahan masalah berupa pengukuran sebelum treatment dan sesudah treatment. Instrumen penelitian 
Jurnal PINUS: Jurnal Penelitian Inovasi Pembelajaran, 5 (2), 2020, Rista Dwi Permata

menggunakan pedoman observasi yang digabungkan dengan check list sebagai pengumpulan data utama. Pengukuran dalam penelitian ini menggunakan rating scale 1-4.

Dalam penelitian ini, peneliti menggunakan rumus Korelasi Product Moment untuk menguji kevalidan dari instrument penelitian. Secara statistik angka korelasi yang diperoleh selanjutnya dibandingkan dengan angka kritis tabel, jika $r$ hitung $\geq r$ tabel maka instrumen dikatakan valid. Sedangkan untuk melakukan uji reliabilitas, peneliti menggunakan Alpha Cronbach $(\alpha)$, yang apabila nilai $\alpha$ lebih besar dari 0.60 maka data penelitian dianggap cukup reliabel.

Rancangan penelitian ini memakai desain one group pretestposttest design, yakni research design yang terdapat pretest sebelum diberi perlakuan dan posttest setelah diberi perlakuan. Dengan begitu dapat diketahui lebih cermat, karena membandingkan dengan diadakan sebelum dan sesudah diberikan perlakuan (Sugiyono, 2001).

Penentuan kelas eksperimen dilakukan dengan cara random sampling. Populasi dalam riset ini adalah grup A TK PKK Harapan Rahayu Kecamatan Soko Kabupaten Tuban yang berjumlah 34 anak yang nantinya dipilih secara acak untuk dijadikan menjadi dua kelompok, yaitu kelas eksperimen (17 anak) dan kelas kontrol (17 anak). Kedua kelompok tersebut sama-sama mendapatkan hal yang sama kecuali treatment, yaitu untuk kelompok eksperimen mendapatkan kegiatan pembelajaran dengan menggunakan media puzzle

\section{HASIL DAN PEMBAHASAN}

Dalam penelitian ini, uji validasi kemampuan pemecahan masalah adalah sebagai berikut:

Tabel 1. Uji Validasi dan Reliabilitas Kemampuan Pemecahan Masalah

\begin{tabular}{|c|c|c|c|c|}
\hline \multicolumn{5}{|c|}{ Item-Total Statistics } \\
\hline & $\begin{array}{l}\text { Scale } \\
\text { Mean If } \\
\text { Item } \\
\text { Deleted }\end{array}$ & $\begin{array}{c}\text { Scale } \\
\text { Variance If } \\
\text { Item } \\
\text { Deleted }\end{array}$ & $\begin{array}{l}\text { Corrected } \\
\text { Item - Total } \\
\text { Correlation }\end{array}$ & $\begin{array}{l}\text { Cronbach's } \\
\text { Alpha if } \\
\text { Item } \\
\text { Deleted }\end{array}$ \\
\hline Indikator_1 & 9.97 & 2.575 & .524 & .722 \\
\hline Indikator_2 & 9.91 & 2.447 & .509 & .729 \\
\hline Indikator_3 & 9.97 & 2.454 & .525 & .720 \\
\hline Indokator_4 & 10.03 & 2.029 & .682 & .628 \\
\hline
\end{tabular}


Jurnal PINUS: Jurnal Penelitian Inovasi Pembelajaran, 5 (2), 2020, Rista Dwi Permata

table, maka instrument penelitian dikatakan valid. Sedangkan untuk uji reliabilitas instrument penelitian apabila nilai Cronbach's Alpha lebih besar dari 0,60 , maka data penelitian dianggap cukup baik dan reliabel.

peneliti melakukan observasi untuk melihat kondisi awal terhadap ketrampilan pemecahan masalah pada anak kelompok A PKK Harapan Rahayu Kecamatan Soko Kabupaten Tuban Tahun Ajaran 2019-2020. Hasil penilaian pra-tindakan dapat cermati pada Tabel.1 berikut:

Tabel.2. Hasil Nilai Observasi Awal dan Akhir Berdasarkan Nilai Rata-Rata terhadap Kemampuan Pemecahan Masalah

\begin{tabular}{lccc}
\hline & Awal & Akhir & Selisih \\
& & & \\
\hline Eksperimen & 8,41 & 14,9 & 6,49 \\
\hline Kontrol & 7,82 & 11,65 & 3,83 \\
\hline
\end{tabular}

Data di atas menunjukkan hasil nilai rata-rata yang hampir sama antara kelas eksperimen dan kelas kontrol pada observasi awal, yakni 8,41 dan 7,82.

Hal ini menunjukkan bahwa kedua kelompok tersebut memiliki tingkat kemampuan pemecahan masalah yang sama. Sedangkan pada hasil observasi akhir memperlihatkan adanya selisih nilai rata-rata antara kelas eksperimen dan kelas kontrol, yaitu 14,9 dan 11, 65. Hal ini berarti dalam penggunaan media permainan puzzle berpengaruh terhadap ketrampilan pemecahan masalah anak.

Dengan selisih yang juga lebih besar antara kelas eksperimen dan kelas kontrol, yakni 6,49 dan 3,83. Uji hipotesis dilakukan setelah uji prasyarat di analisis dan digunakan untuk menguji hipotesis.

Berdasarkan perbandingan nilai jika nilai Sig (2-tailed) $<0,05$, maka terdapat perbedaan yang signifikan antara kelompok eksperimen dan kelompok kontrol. Jika nilai Sig (2tailed) > 0,05, maka tidak terdapat perbedaan yang signifikan antara kelompok eksperimen dan kelompok kontrol. Dengan pengujian menggunakan uji Independent Sample Test, maka diperoleh hasil sebagai berikut:

Tabel 3. Uji Independent Sample Test

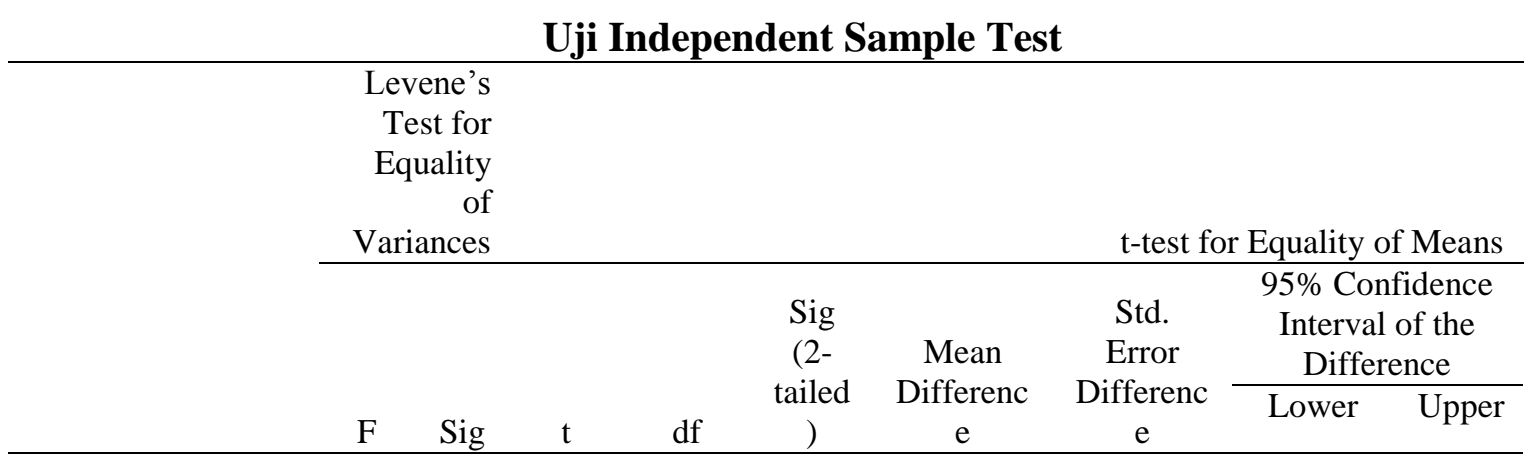


Jurnal PINUS: Jurnal Penelitian Inovasi Pembelajaran, 5 (2), 2020, Rista Dwi Permata

\begin{tabular}{rrrrrrrrrrr}
\hline Postt & Equal & .82 & .37 & 8.95 & 32 & .000 & 3.29412 & .36794 & 2.5446 & 4.0435 \\
est & variances & 3 & 1 & 3 & & & & & 5 \\
& assumed & & & & & & & & & \\
& Equal & & & & & & & & \\
& Variances & & & 8.95 & 30.90 & .000 & 3.29412 & .36794 & 2.5436 & 4.0446 \\
not & & & 3 & 2 & & & & 0 & 3
\end{tabular}

Berdasarkan tabel 2 diatas, diperoleh hasil uji Independent Samples Test dengan nilai Sig (2-tailed) sebesar $0,000<0,05$ yang artinya terdapat perbedaan yang signifikan antara kelompok eksperimen dan kontrol dalam kemampuan pemecahan masalah anak.

\section{KESIMPULAN}

Berdasarkan riset yang telah dilakukan mengenai pengaruh penggunaan media permainan puzzle terhadap kemampuan pemecahan masalah pada anak usia dini, maka dapat ditarik kesimpulan, yaitu terdapat pengaruh dalam penggunaan media puzzle terhadap kemampuan pemecahan masalah anak kelompok A TK PKK Harapan Rahayu Kecamatan Soko Kabupaten Tuban. Adapun diperoleh nilai signifikansi dari perhitungan menggunakan uji Independent Samples Test yaitu nilai sig (2- tailed) sebesar $0,000<0,05$ sehingga dapat diambil kesimpulan bahwa Ho ditolak dan $\mathrm{Ha}$ diterima.

Hal tersebut sesuai dengan pernyataan (Martuti), yang menyebutkan bahwa kelebihan dari bermain puzzle bagi anak-anak, salah satunya adalah meningkatkan keterampilan kognitif (cognitive skill) yang berhubungan dengan ketrampilan untuk belajar dan menyelesaikan masalah. Aktivitas bermain menggunakan media puzzle akan mengimplikasikan kerjasama antara tangan dengan mata sehingga anak memiliki keahlian dalam mendalami sesuatu hal menurut kemampuan dan minat anak.

Berdasarkan simpulan diatas, maka disarankan untuk pendidik agar menggunakan media puzzle dalam kegiatan pembelajaran supaya dapat meningkatkan kemampuan pemecahan masalah anak usia dini dan juga menjadikan kegiatan pembelajaran menjadi lebih menyenangkan bagi anak.

\section{DAFTAR RUJUKAN}

Al-Azizy, A. Suciaty. Ragam Latihan Khusus Asah Ketajaman Otak Anak Plus Melejitkan Daya Ingatnya. Jogjakarta: Diva Press, 2010.

Depdiknas. Petunjuk Teknik Penyelenggaraan Pendidikan Anak Usia Dini. Depdiknas, 2006.

Kent, G., Pitsia, V., \& Colton, G. Cognitive Development during Early Childhood: Insights from Families Living in Areas of SocioEconomic Disadvantage. Early 
Jurnal PINUS: Jurnal Penelitian Inovasi Pembelajaran, 5 (2), 2020, Rista Dwi Permata

Child Development and Care. 2018, doi:doi:10.1080/03004430.2018.15 43665 .

Malahayati. 50 Permainan Melatih Kecerdasan Anak. Nusantara Publisher, 2009.

Maria, Montessori. "The Absorbent Mind, Pikiran Yang Mudah Menyerap, Terjemahan Dariyatno." Yogyakarta: Pustaka Pelajar, 2008.

Martuti, Am. "Mengelola PAUD Dengan Aneka Permainan Meraih Kecerdasan Majemuk." Yogyakarta: Kreasi Wacana, 2008.

Masyah, Maretha. Meningkatkan Kemampuan Pemecahan Masalah Melalui Bermain Tebak Gambar Pada Anak Kelompok Al Di PAUD Kemala Bhayangkari Bengkulu Utara. 2017, doi:DOI: https://doi.org/10.33369/jip.2.2.101 $-106$.

Mutiah, Diana. Psikologi Bermain Anak Usia Dini. Kencana, 2015.

Safitri, D., Syukri, M., \&. Yuniarni D. Meningkatkan Kemampuan PPeningkatan Kemampuan Daya Ingat Melalui Permainan Puzzle
Pada Anak Usia 5-6 Tahun. Universitas Tanjungpura Pontianak. 2014, http://jurnal.untan.ac.id/index.php/j pdpb/article/view/5667.

Santrock, John W. Psikologi Pendidikan Edisi Kedua. Kencana Prenada Media Group, 2010.

Setyowati, Novita Dwi. Penerapan Permainan Kreatif Mencari Harta Karun Untuk Meningkatkan Kemampuan Memecahkan Masalah Pada Anak Kelompok B Di Taman Kanak-Kanak. 2018, doi:. https://doi.org/10.29407/pn.v3i2.11 872.

Sugiyono. Metode Penelitian. CV Alfabet, 2001.

Sujiono, Yuliani Nurani. Konsep Dasar Pendidikan Anak Usia Dini. Indeks, 2013.

Syaodih, E., Setiasih., dkk. Pengembangan Kemampuan Pemecahan Masalah Anak Usia Dini Dalam Pembelajaran Proyek Di Taman Kanak-Kanak. 2018, https://doi.org/10.21009/JPUD.121 03. 